\title{
Dopamine $\beta$-Hydroxylase Knockout Mice have Alterations in Dopamine Signaling and are Hypersensitive to Cocaine
}

\author{
Jesse R Schank ${ }^{1,6}$, Rossella Ventura ${ }^{2,3,6}$, Stefano Puglisi-Allegra ${ }^{2,3}$, Antonio Alcaro ${ }^{2,3}$, Charlene D Cole ${ }^{1,4}$, \\ L Cameron Liles', Philip Seeman ${ }^{5}$ and David Weinshenker*, I \\ 'Department of Human Genetics, Emory University, Atlanta, GA, USA; ²Dipartimento di Psicologia, Università 'La Sapienza', Rome, Italy; ${ }^{3}$ Istituto \\ di Ricovero e Cura a Carattere Scientifico Fondazione Santa Lucia, Rome, Italy; ${ }^{4}$ Center for Behavioral Neuroscience, Emory University, Atlanta, \\ GA, USA; ${ }^{5}$ Department of Pharmacology, University of Toronto, Toronto, ON, Canada
}

\begin{abstract}
Multiple lines of evidence demonstrate that the noradrenergic system provides both direct and indirect excitatory drive onto midbrain dopamine (DA) neurons. We used DA $\beta$-hydroxylase $(\mathrm{DBH})$ knockout (Dbh-/-) mice that lack norepinephrine (NE) to determine the consequences of chronic NE deficiency on midbrain DA neuron function in vivo. Basal extracellular DA levels were significantly attenuated in the nucleus accumbens (NAc) and caudate putamen (CP), but not prefrontal cortex (PFC), of Dbh-1- mice, while amphetamine-induced DA release was absent in the NAc and attenuated in the CP and PFC. The decrease in dopaminergic tone was associated with a profound increase in the density of high-affinity state $D_{1}$ and $D_{2} D A$ receptors in the NAc and $C P$, while DA receptors in the PFC were relatively unaffected. As a behavioral consequence of these neurochemical changes, Dbh-/- mice were hypersensitive to the psychomotor, rewarding, and aversive effects of cocaine, as measured by locomotor activity and conditioned place preference. Antagonists of DA, but not 5-HT, receptors attenuated the locomotor hypersensitivity to cocaine in Dbh-l- mice. As DBH activity in humans is genetically controlled and the $\mathrm{DBH}$ inhibitor disulfiram has shown promise as a pharmacotherapy for cocaine dependence, these results have implications for the influence of genetic and pharmacological DBH inhibition on DA system function and drug addiction.
\end{abstract}

Neuropsychopharmacology (2006) 31, 222 I-2230. doi:I0.1038/s.npp. I30 I000; published online 14 December 2005

Keywords: norepinephrine; dopamine; dopamine $\beta$-hydroxylase; cocaine; amphetamine; mice

\section{INTRODUCTION}

Brainstem noradrenergic neurons project both directly and indirectly to midbrain dopamine (DA) neurons, where they regulate firing patterns and DA release (Swanson and Hartman, 1975; Jones and Moore, 1977; Grenhoff et al, 1993; Grenhoff and Svensson, 1993; Darracq et al, 1998; Ventura et al, 2003; Liprando et al, 2004). DA $\beta$-hydroxylase (DBH) controls norepinephrine (NE) production and the NE/DA ratio in noradrenergic neurons and modulates the activity of the DA system and certain psychostimulant-induced behaviors. This pathway has recently become of particular interest for three reasons: (1) a common, single-base polymorphism in the human $D b h$ gene that controls DBH

\footnotetext{
*Correspondence: Dr D Weinshenker, Department of Human Genetics, Emory University School of Medicine, Whitehead 301, 615 Michael Street, Atlanta, GA 30322, USA, Tel: + I 404727 3106, Fax: + | 404727 3949, E-mail: dweinshenker@genetics.emory.edu

${ }^{6}$ These two authors contributed equally to this work.

Received 29 April 2005; revised 7 September 2005; accepted 13 September 2005

Online publication: I November 2005 at http://www.acnp.org/citations/ Npp I $0105050278 /$ default.pdf
}

enzymatic activity has been identified (Zabetian et al, 2001); (2) DBH activity affects responses to cocaine in humans, and recent studies indicate that the DBH inhibitor disulfiram has efficacy as a treatment for cocaine dependence (Carroll et al, 1998, 2004; Cubells et al, 2000; George et al, 2000; Petrakis et al, 2000); and (3) Dbh knockout $(D b h-/-)$ mice have changes in DA receptor signaling and are hypersensitive to the psychomotor effects of amphetamine (Weinshenker et al, 2002). Therefore, it is of interest to understand the influence of $\mathrm{DBH}$ and the noradrenergic system on DA neuron function.

The psychostimulants cocaine and amphetamine facilitate release and/or block reuptake of DA, NE, and 5-HT, resulting in increased synaptic availability of these neurotransmitters. The mesolimbic and mesocortical DA systems, comprised of projections from the VTA to the nucleus accumbens (NAc) and prefrontal cortex (PFC), respectively, have been primarily implicated in both the reinforcing and aversive effects of these drugs of abuse (Koob et al, 1998; Spanagel and Weiss, 1999). While DA pathways and signaling have been the focus of most psychostimulant addiction research, it is also clear that $\mathrm{NE}$ plays an important role in modulating responses to psychostimu- 
lants. For example, lesions of noradrenergic neurons, administration of the $\alpha_{1}$-adrenoreceptor $\left(\alpha_{1} \mathrm{AR}\right)$ antagonist prazosin, or targeted disruption of the $\alpha_{1 \mathrm{~B}} \mathrm{AR}$ attenuate the psychomotor effects of psychostimulants in rodents (Snoddy and Tessel, 1985; Mohammed et al, 1986; Darracq et al, 1998; Drouin et al, 2002a, b). Paradoxically, we found that $D b h$ knockout $(D b h-/-)$ mice are hypersensitive to the psychomotor effects of amphetamine (Weinshenker et al, 2002), indicating that differences exist between chronic NE deficiency and disruption of a single adrenergic receptor or relatively acute losses of $\mathrm{NE}$ signaling. In addition, amphetamine-induced accumbal DA release and place preference are lost in mice with $\mathrm{NE}$ depletion in the PFC, suggesting that psychostimulant reward depends on a functional noradrenergic system (Ventura et al, 2003).

As the noradrenergic system has a facilitory effect on DA neurons, we hypothesized that DA release would be compromised in $\mathrm{Dbh}-/-$ mice and that a compensatory increase in DA receptor signaling might underlie the hypersensitivity of $\mathrm{Dbh}-/-$ mice to amphetamine. To identify neurochemical changes associated with the amphetamine hypersensitivity in $D b h-/-$ mice, we assessed DA release by microdialysis and high-affinity state DA receptors by radioligand binding in vitro. To further explore the effects of chronic DBH inhibition and NE deficiency on behavioral responses to psychostimulants, we tested cocaine-induced locomotion, reward, and aversion.

\section{MATERIALS AND METHODS}

\section{Mouse Breeding and Genotyping}

Dbh-/- mice, maintained on a mixed 129/SvEv and C57BL/ $6 \mathrm{~J}$ background, were developed and generated as described (Thomas et al, 1995, 1998). Dbh-/- males were bred to $D b h+/-$ females. Pregnant $D b h+/-$ mice were given the AR agonists isoproterenol and phenylephrine $(20 \mu \mathrm{g} / \mathrm{ml}$ each) + vitamin C $(2 \mathrm{mg} / \mathrm{ml})$ from E9.5-E14.5, and $\mathrm{L}-3,4-$ dihydroxyphenylserine (DOPS; $2 \mathrm{mg} / \mathrm{ml}+$ vitamin C $2 \mathrm{mg} /$ $\mathrm{ml}$ ) from E14.5 to birth in their drinking water to rescue the embryonic lethality associated with the homozygous Dbh-/- mutation. Owing to this treatment, NE and epinephrine were present in $D b h-/-$ animals before but not after birth. Dbh-/- mice were identified by the delayed growth and ptosis phenotypes, which are $100 \%$ correlated with the $D b h-/-$ genotype. Genotypes were confirmed by PCR. Dbh $+/-$ mice were used as controls because they have normal catecholamine levels and are indistinguishable from $D b h+/+$ mice for all previously tested phenotypes (Thomas et al, 1995, 1998). All mice were reared in a specific pathogen-free facility with a $12 \mathrm{~h}$ light/dark cycle (lights on at $0700 \mathrm{~h}$, lights off at $1900 \mathrm{~h}$ ); food and water were available ad libitum. Naïve mice between 3 and 6 months of age were used for all experiments. Both male and female mice were used for all experiments. No sex differences were observed, and results were combined.

Experimental protocols were approved by the animal care committee at Emory University, and meet the guidelines of the American Association for Accreditation of Laboratory Animal Care and Italian national law (DL no. 116, 1992) governing the use of animals for research.

\section{Locomotor Activity}

Experiments were conducted in an isolated behavior room between 1000 and $1600 \mathrm{~h}$. Ambulations (consecutive beam breaks) were measured in transparent plexiglass cages $\left(40 \times 20 \times 20 \mathrm{~cm}^{3}\right)$ placed into a rack with seven infrared photobeams spaced $5 \mathrm{~cm}$ apart, each end beam $5 \mathrm{~cm}$ from the cage wall (San Diego Instruments Inc., LaJolla, CA). Mice were placed in the activity chambers for $4 \mathrm{~h}$, injected with cocaine $(5,10$, or $20 \mathrm{mg} / \mathrm{kg}$ i.p.; Sigma-Aldrich, St Louis, MO), and ambulations were recorded for an additional $2 \mathrm{~h}$. Data were analyzed by ANOVA followed by Bonferroni post-hoc tests. For the antagonist studies, saline, the $5-\mathrm{HT}_{1 \mathrm{~A}}$ antagonist WAY100635 $(0.03 \mathrm{mg} / \mathrm{kg})$, the $5-\mathrm{HT}_{2}$ antagonist ketanserin $(0.3 \mathrm{mg} / \mathrm{kg})$, the $\mathrm{D}_{1}$ antagonist SCH23390 $(0.03 \mathrm{mg} / \mathrm{kg})$, or the $\mathrm{D}_{2}$ antagonist eticlopride were injected i.p. $30 \mathrm{~min}$ prior to cocaine $(20 \mathrm{mg} / \mathrm{kg})$. Antagonist doses were chosen based on the literature and our pilot experiments; higher doses were tried, but typically resulted in sedation and ataxia, indicating nonspecific effects. All drugs were purchased from Sigma-Aldrich (St Louis, MO).

\section{Radioligand Binding}

Mice were euthanized by $\mathrm{CO}_{2}$ asphyxiation, and brains were quickly removed and dissected on ice. Dissections were guided by the mouse brain atlas (Paxinos and Franklin, 1997). The frontal cortex was isolated by removing the olfactory bulb and making a cut $1 \mathrm{~mm}$ caudal to the beginning of the brain proper. As this region is comprised mostly of PFC and related structures, it will be subsequently referred to as the PFC. The striatum was isolated by making a second cut $1.5 \mathrm{~mm}$ caudal to the first cut, then cutting away the cortex, the most medial structures including the septum and diagonal band, and the most ventral structures including the olfactory tubercle and ventral pallidum. Each remaining hemisphere was then cut horizontally just above the anterior commmissure to isolate the dorsal striatum caudate putamen (CP) and NAc. Brain tissue was then placed in microfuge tubes, frozen on dry ice, and stored at $-70^{\circ} \mathrm{C}$ until used. As $\sim 30 \mathrm{mg}$ of tissue was required for each assay, tissue from eight mice per genotype was batched.

$\mathrm{D}_{2}$ receptor radioligand binding experiments were performed as described (Seeman et al, 2002). Briefly, tissue was homogenized in buffer $(50 \mathrm{mM}$ Tris- $\mathrm{HCl}, \mathrm{pH} 7.4,1 \mathrm{mM}$ EDTA, $\left.5 \mathrm{mM} \mathrm{KCl}, 1.5 \mathrm{mM} \mathrm{CaCl}{ }_{2}\right)$ with or without $200 \mu \mathrm{M}$ guanilylimidodiphosphate (guanine nucleotide (GN)), and placed in glass test tubes, followed by the addition of $\left[{ }^{3} \mathrm{H}\right]$ raclopride $(76.8 \mathrm{Ci} / \mathrm{mmol} ; 12$ final concentrations, from 0.2 to $20 \mathrm{nM}$ ). Samples were incubated at room temperature and passed through a filter, which was then rinsed, placed in vials of scintillant, and monitored $6 \mathrm{~h}$ later for tritium using a spectrometer. Nonspecific binding for $\mathrm{D}_{2}$ receptors was defined as that which occurred in the presence of $10 \mu \mathrm{M}$ S-sulpiride (Ravizza, Milan, Italy). The density $\left(B_{\max }\right)$ and dissociation constant $\left(K_{\mathrm{d}}\right)$ of $\left[{ }^{3} \mathrm{H}\right]$ raclopride-binding sites were obtained by Scatchard analysis. Scatchard analysis was performed in triplicate on each tissue batch, and the receptor density values were consistently within $5-8 \%$ of each other. $D_{1}$ receptor density was measured by the same 
procedure, except that the ligand was $\left[{ }^{3} \mathrm{H}\right] \mathrm{SCH} 23390(75.5$ Curies $/ \mathrm{mmol}$ ) and nonspecific binding was defined by $1 \mu \mathrm{M}$ (+)butaclamol. $\left[{ }^{3} \mathrm{H}\right]$ raclopride $K_{\mathrm{d}}$ values ranged from 1 to $2.5 \mathrm{nM}$, and $\left[{ }^{3} \mathrm{H}\right] \mathrm{SCH} 23390 K_{\mathrm{d}}$ values ranged from 0.21 to $0.49 \mathrm{nM}$, similar to published values. The addition of GN consistently elevated the $K_{\mathrm{d}}$ of $\left[{ }^{3} \mathrm{H}\right]$ raclopride, reflecting the release of endogenous DA, which then competes with $\left[{ }^{3} \mathrm{H}\right]$ raclopride. The addition of GN did not affect the $K_{\mathrm{d}}$ of $\left[{ }^{3} \mathrm{H}\right] \mathrm{SCH} 23390$. Each binding assay was performed three times on separate days, and the absolute values for the total receptor densities varied 5-8\% from day to day. Therefore, it was more reliable to measure the difference caused by GN on the receptor density in the $D b h+/-$ and $D b h-/-$ samples on the same day. This procedure permitted the reliable detection of differences in DA receptor densities which ranged from 0.7 to $11.7 \mathrm{pmol} / \mathrm{g}$ for $\mathrm{D}_{1}$ and from 0.4 to $10.3 \mathrm{pmol} / \mathrm{g}$ for $\mathrm{D}_{2}$. The net difference caused by GN varied by less than $10 \%$ for the triplicate experiments.

\section{Microdialysis}

Upon their arrival, animals were housed in groups of four in standard breeding cages $\left(27 \times 21 \times 13.5 \mathrm{~cm}^{3}\right)$, with food and water ad libitum on a $12 / 12 \mathrm{~h}$ dark/light cycle (light on between 0700 and $1900 \mathrm{~h}$ ). All mice used were handled and accustomed to the environment where the experiment was to be performed and then randomly assigned to different treatments. All experiments were carried out between 1400 and $1800 \mathrm{~h}$.

Animals were anesthetized with chloral hydrate $(450 \mathrm{mg} /$ $\mathrm{kg}$ ), mounted in a stereotaxic frame (David Kopf Instruments, Tujunga, CA) equipped with a mouse adapter, and implanted unilaterally with a guide cannula (stainless steel, shaft OD $0.38 \mathrm{~mm}$, Metalant $\mathrm{AB}$, Stockholm, Sweden) in the $\mathrm{CP}$, NAc, or PFC. The length of the guide cannula was: $2.5 \mathrm{~mm}$ for the CP, $4 \mathrm{~mm}$ for the NAc, and $1 \mathrm{~mm}$ for the PFC. The guide cannula was fixed with epoxy glue, and dental cement was added for further stabilization. The coordinates from bregma, measured in $\mathrm{mm}$ according to the mouse brain atlas (Paxinos and Franklin, 1997), were: +1.0 anteroposterior and +1.4 lateral for the $\mathrm{CP},+1.4$ anteroposterior and +0.6 lateral for the NAc (mostly including the shell subdivision; Paxinos and Franklin, 1997; Ventura et al, 2003), and +2.52 anteroposterior and 0.6 lateral for the PFC. The probe (dialysis membrane length $2 \mathrm{~mm}$ for $\mathrm{CP}$ and PFC and $1 \mathrm{~mm}$ for NAc; o.d. $0.24 \mathrm{~mm}$, $\mathrm{MAB} 4$ cuprophane microdialysis probe, Metalant $\mathrm{AB}$ ) was introduced $24-48 \mathrm{~h}$ after implantation of the guide cannula. The animals were lightly anesthetized with chloral hydrate $(225 \mathrm{mg} / \mathrm{kg})$ to facilitate manual insertion of the microdialysis probe into the guide cannula. The membranes were tested for in vitro recovery of DA on the day before use in order to verify recovery.

The microdialysis probe was connected to a CMA/100 pump (Carnegie Medicine, Stockholm, Sweden) through PE-20 tubing and an ultra-low torque dual-channel liquid swivel (Model 375/D/22QM, Instech Laboratories, Inc., Plymouth Meeting, PA) to allow free movement. Artificial CSF $(147 \mathrm{mM} \mathrm{NaCl}, 2.2 \mathrm{mM} \mathrm{CaCl} 2$ and $4 \mathrm{mM} \mathrm{KCl}$ ) was pumped through the dialysis probe at a constant flow rate of $2 \mu \mathrm{l} / \mathrm{min}$. Experiments were carried out $22-24 \mathrm{~h}$ after probe placement. Each animal was placed in a circular cage
$(21.5 \mathrm{~cm}$ in height, $17.5 \mathrm{~cm}$ in diameter) provided with microdialysis equipment (Instech Laboratories, Inc.) and with home cage bedding on the floor. Dialysis perfusion was started $1 \mathrm{~h}$ later. Following the start of dialysis perfusion, mice were left undisturbed for approximately $2 \mathrm{~h}$ before the collection of baseline samples. Following baseline sample collection (1 sample every $20 \mathrm{~min}$ for $60 \mathrm{~min}$ ), mice were injected with saline or amphetamine $(2.5 \mathrm{mg} / \mathrm{kg}$, i.p.), and dialysate was collected every $20 \mathrm{~min}$ for $120 \mathrm{~min}$. Only data from mice with correctly placed cannula (judged by methylene blue staining) were reported. In all, $20 \mu$ lof the dialysate samples was analyzed by high-performance liquid chromatography (HPLC). The remaining $20 \mu \mathrm{l}$ was kept for possible subsequent analysis. Concentrations (pg/20 $\mu \mathrm{l}$ ) were not corrected for probe recovery. The mean concentration of the three samples collected immediately before treatment (less than $10 \%$ variation) was taken as basal concentration.

The HPLC system consisted of an Alliance (Waters Corporation, Milford, MA) system and a coulometric detector (ESA Model 5200A Coulochem II) provided with a conditioning cell (M 5021) and an analytical cell (M 5011). The conditioning cell was set at $400 \mathrm{mV}$, electrode 1 at $200 \mathrm{mV}$, and electrode 2 at $-250 \mathrm{mV}$. A Nova-Pack C18 column $(3.9 \times 150 \mathrm{~mm}$, Waters $)$ maintained at $33^{\circ} \mathrm{C}$ was used. The flow rate was $1.1 \mathrm{ml} / \mathrm{min}$. The mobile phase was as described previously (Ventura et al, 2003). The assay detection limit was $0.1 \mathrm{pg}$.

Statistical analyses were performed on raw data (concentrations, pg/20 $\mathrm{ll}$ ). The effects of amphetamine on extracellular monoamine levels in the CP, NAc, or PFC were analyzed by repeated-measures ANOVA with two between-factor (strain, two levels: $D b h+/-$ and $D b h-/-$; treatment, two levels: amphetamine and saline) and one within-factor (minutes, seven levels: $0,20,40,60,80,100$, and 120). Simple effects were assessed by one-way ANOVA for each time point. Individual between-group comparisons, when appropriate, were performed by post-hoc test (Duncan's multiple range test).

\section{Conditioned Place Preference}

Experiments were conducted in an isolated behavior room between 1000 and $1600 \mathrm{~h}$. Mice were placed in the 'neutral' middle compartment of a three-compartment conditioned place preference chamber (San Diego Instruments, La Jolla, $\mathrm{CA}$ ) and allowed to freely explore the other two compartments that were distinguishable by floor texture and wall pattern for $20 \mathrm{~min}$, and time spent in each compartment was recorded ('pretest'). After 1-6 days, mice were subjected to 'conditioning' sessions for three consecutive days. Mice were given an injection of saline $(10 \mathrm{ml} / \mathrm{kg}$, i.p.) and restricted to one compartment for $30 \mathrm{~min}$ in the morning, then given an i.p. injection of saline or cocaine $(5,10,20,40$, or $60 \mathrm{mg} / \mathrm{kg}, 10 \mathrm{ml} / \mathrm{kg}$ ) and restricted to the other compartment for $30 \mathrm{~min}$ in the afternoon $(\sim 4 \mathrm{~h}$ after the morning conditioning session). Mice were designated to receive cocaine on either the ' $\mathrm{A}$ ' side or ' $\mathrm{B}$ ' side using an unbiased design (ie for each genotype, equal numbers of mice received cocaine on each side, and equal numbers of mice received cocaine on the 'preferred' side and 'nonpreferred' side based on pretest results). The day following the last 
conditioning session, mice were placed in the neutral middle compartment in a drug-free state, allowed to freely explore all compartments for $20 \mathrm{~min}$, and time spent in each compartment was recorded. Testing sessions were begun roughly halfway between the morning and afternoon conditioning sessions of the third day of conditioning. The preference score was calculated by subtracting the amount of time spent on the saline-paired side from the amount of time spent on the cocaine-paired side. Data were analyzed by paired $t$-tests (pretest preference $v s$ post-test preference for each group).

\section{RESULTS}

Basal and Amphetamine-Induced DA Release is Attenuated in $\mathrm{Dbh}-/$ - Mice

As the activity of mesolimbic dopaminergic neurons is enhanced by NE, we predicted that striatal DA release would be compromised in $D b h-/-$ mice. We assessed DA release in the NAc, CP, and PFC of awake, behaving $D b h+/-$ and Dbh-/- mice by microdialysis. Basal extracellular DA levels were significantly reduced in the NAc and $\mathrm{CP}$, but not the PFC, of Dbh-/- mice (NAc: $D b h+/-1.25 \pm 0.25 \mathrm{pg} / 20 \mu \mathrm{l}$, Dbh-/- $0.56 \pm 0.5, \quad P<0.05 ; \quad$ CP: $D b h+/-1.99 \pm 0.27$, Dbh-/- 1.32 $\pm 0.11, P<0.05$; PFC: $D b h+/-0.56 \pm 0.03$, Dbh-/- 0.47 \pm 0.03$)$. Basal extracellular NE levels were $1.02 \pm 0.13$ in the PFC and $0.62 \pm 0.09$ in the NAc of $D b h+/-$ mice, while NE was undetectable in $\mathrm{Dbh}-/-$ mice.

The effects of amphetamine on DA release are shown in Figure 1. Extracellular DA levels in the NAc, CP, and PFC of $\mathrm{Dbh}+/-$ mice were increased dramatically by amphetamine administration $(2.5 \mathrm{mg} / \mathrm{kg}$, i.p.), peaking at $\sim 100 \%$ maximal increase in the NAc and CP and $\sim 200 \%$ maximal increase in the PFC. In contrast, the amphetamine-induced increase in extracellular DA was absent in the NAc, and present but reduced in the CP (50\% maximal increase) and PFC (75\% maximal increase) of $D b h-/-$ mice. Statistical analyses revealed a significant strain $\times$ treatment $\times$ minutes interaction for the NAc $\left(\mathrm{F}_{6,226}=3.44 ; P<0.005\right), \quad \mathrm{CP}$ $\left(\mathrm{F}_{6,120}=2.23 ; P<0.05\right)$, and PFC $\left(\mathrm{F}_{6,114}=2.30 ; P<0.05\right)$. Post hoc analysis revealed significant differences between $D b h+/-$ and $D b h-/-$ mice challenged with amphetamine at multiple time points (Figure 1).

\section{Increased Density of Striatal High-Affinity State DA Receptors in $D b h-/-$ Mice}

Reductions in striatal DA availability typically result in the upregulation of striatal DA receptors. In addition, $D b h-/-$ mice share a number of phenotypes with wild-type animals that have undergone psychostimulant sensitization, including greater psychostimulant- and $\mathrm{D}_{2}$ agonist-induced

Figure I Amphetamine-induced DA release is attenuated in Dbh-/mice. Shown are extracellular DA levels in the (a) NAc, (b) CP, and (c) PFC of Dbh $+1-$ and Dbh-/- mice after administration of saline (sal) or amphetamine (amph; $2.5 \mathrm{mg} / \mathrm{kg}$, i.p.; $N=5-$ I I per genotype and treatment group). Values are expressed as mean \pm SEM. ${ }^{*} P<0.05$ compared to amphetamine-treated $\mathrm{Dbh}-1-$ mice for that time point. ${ }^{\#} P<0.05$ compared to saline-treated mice of the same genotype for that time point. locomotion, and an increase in striatal high-affinity state $\mathrm{D}_{2}$ receptors is thought to contribute to these phenotypes in sensitized animals (Seeman et al, 2002, 2005; Weinshenker
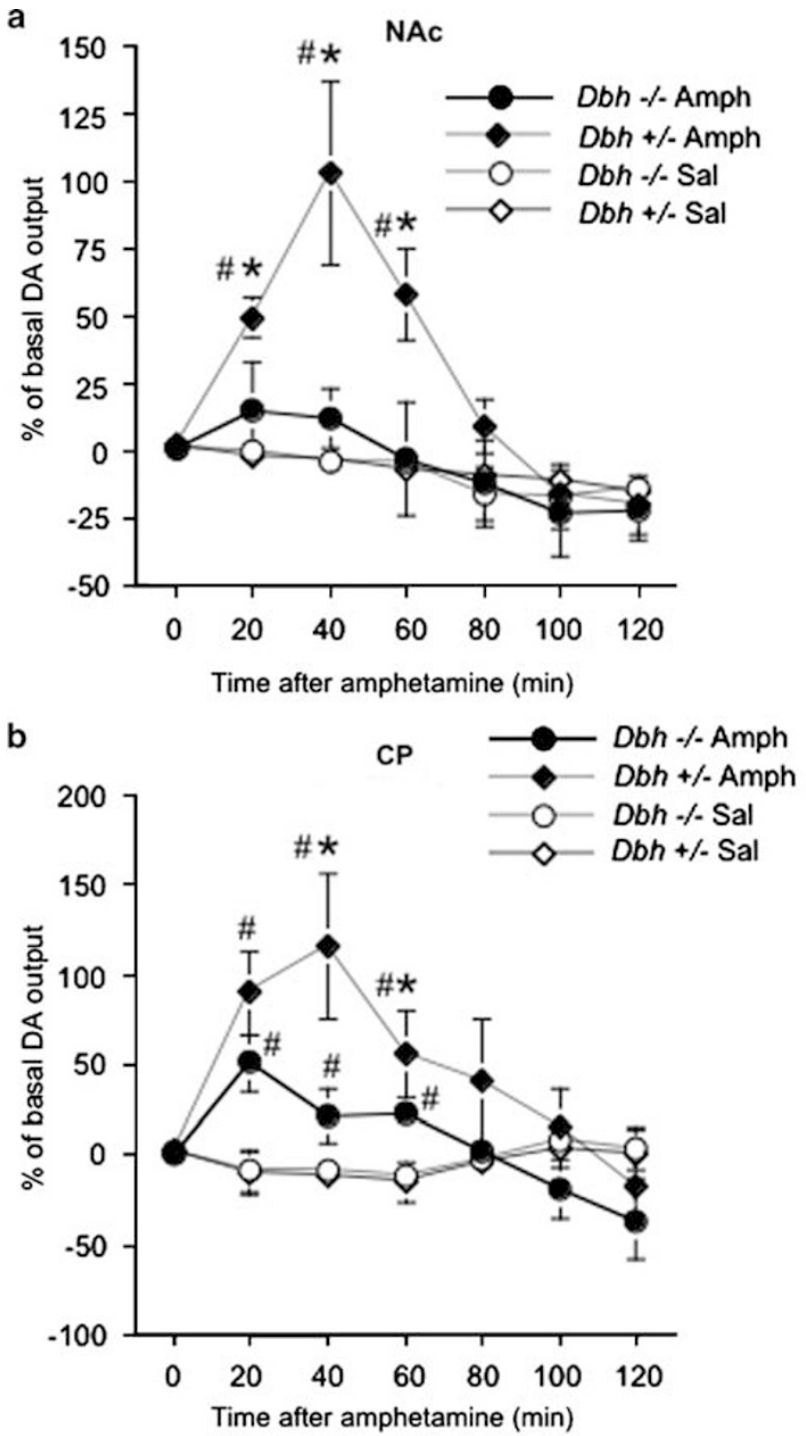

C

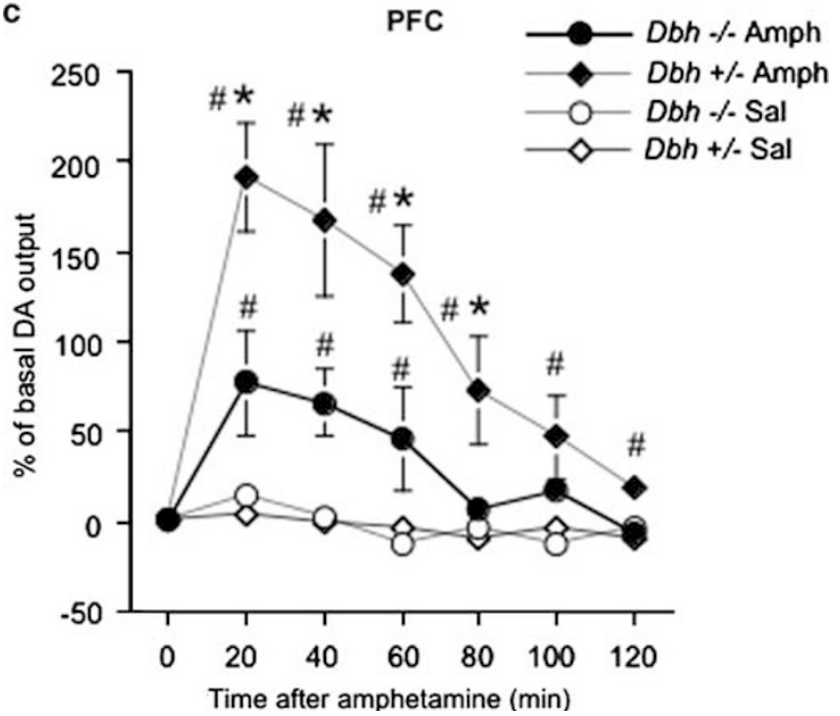


et al, 2002). We measured saturation binding of the $D_{1}$ antagonist $\mathrm{SCH} 23390$ and the $\mathrm{D}_{2}$ antagonist raclopride to brain tissue homogenates in the presence and absence of GN. Under normal conditions, antagonist binding to highaffinity state receptors is prevented by endogenous DA, but previous data are consistent with the principle that GN permits the release of receptor-bound DA and allows the binding of the antagonist to all receptors (Seeman et al, 1989). Thus, the difference in antagonist binding in the presence and absence of GN represents the density of highaffinity state receptors.

While no large differences in total striatal DA receptors were found between $\mathrm{Dbh}+/-$ and $-/-$ mice, high-affinity state DA receptors were markedly elevated in $D b h-/-$ mice $\left(\mathrm{D}_{1}\right.$ receptors: $1.9 \mathrm{pmol} / \mathrm{g}$ for $\mathrm{D} b \mathrm{~h}+/-$ mice, $5.7 \mathrm{pmol} / \mathrm{g}$ for $D b h-/-$ mice in the CP; $6.6 \mathrm{pmol} / \mathrm{g}$ for $D b h+/-$ mice, $11.7 \mathrm{pmol} / \mathrm{g}$ for $\mathrm{D} b \mathrm{~h}-/ \mathrm{-}$ mice in the NAc; $\mathrm{D}_{2}$ receptors: $3.7 \mathrm{pmol} / \mathrm{g}$ for $\mathrm{D} b \mathrm{~h}+/ \mathrm{-}$ mice, $10.3 \mathrm{pmol} / \mathrm{g}$ for $\mathrm{D} b h-/-$ mice in the CP; $0.8 \mathrm{pmol} / \mathrm{g}$ for $D b h+/-$ mice, $5.3 \mathrm{pmol} / \mathrm{g}$ for $D b h-/-$ mice in the NAc; Figure $2 \mathrm{a}-\mathrm{d}$ ). Similar results were obtained when antagonist binding to total striatal homogenates was examined independently from separate groups of animals and when two other methods of measuring highaffinity state receptors were used $\left(\mathrm{DA} /\left[\mathrm{H}^{3}\right]\right.$ raclopride or
$\mathrm{DA} /\left[{ }^{3} \mathrm{H}\right]$ domperidone competition; Seeman et al, 2005). In contrast, the density of high-affinity state DA receptors in the PFC of $D b h-/-$ mice was similar to that of controls $\left(D_{1}\right.$ receptors: $0.7 \mathrm{pmol} / \mathrm{g}$ for $D b h+/-$ mice, $0.7 \mathrm{pmol} / \mathrm{g}$ for Dbh-/- mice; $\mathrm{D}_{2}$ receptors: $0.4 \mathrm{pmol} / \mathrm{g}$ for $\mathrm{Dbh}+/-$ mice, $0.6 \mathrm{pmol} / \mathrm{g}$ for $\mathrm{Dbh}-/-$ mice, and total $\mathrm{D}_{2}$ receptor density was modestly reduced (Figure $2 \mathrm{e}$ and $\mathrm{f}$ ).

\section{Dbh-/- Mice are Hypersensitive to Cocaine-Induced Locomotion}

We have previously shown that $D b h-/-$ mice are hypersensitive to amphetamine-induced locomotion and stereotypy (Weinshenker et al, 2002). To determine whether this hypersensitivity extends to cocaine, we measured the locomotor response of $\mathrm{Dbh}+/-$ and $\mathrm{Dbh}-/-$ mice to cocaine. Cocaine produced a dose-dependent increase in locomotor activity in both $D b h+/-$ and $-/-$ mice (Figure 3). However, as with amphetamine, cocaine-induced locomotion was greater in $\mathrm{Dbh}-\mathrm{/}-$ mice at all doses tested; there was a significant genotype $\times$ time interaction for $5 \mathrm{mg} / \mathrm{kg}\left(\mathrm{F}_{11,168}=6.82, P<0.0001\right), 10 \mathrm{mg} / \mathrm{kg}\left(\mathrm{F}_{11,168}=8.80\right.$, $P<0.0001)$, and $20 \mathrm{mg} / \mathrm{kg}$ cocaine $\left(\mathrm{F}_{11,144}=5.52, P<0.0001\right)$. Post hoc analysis revealed significant differences between
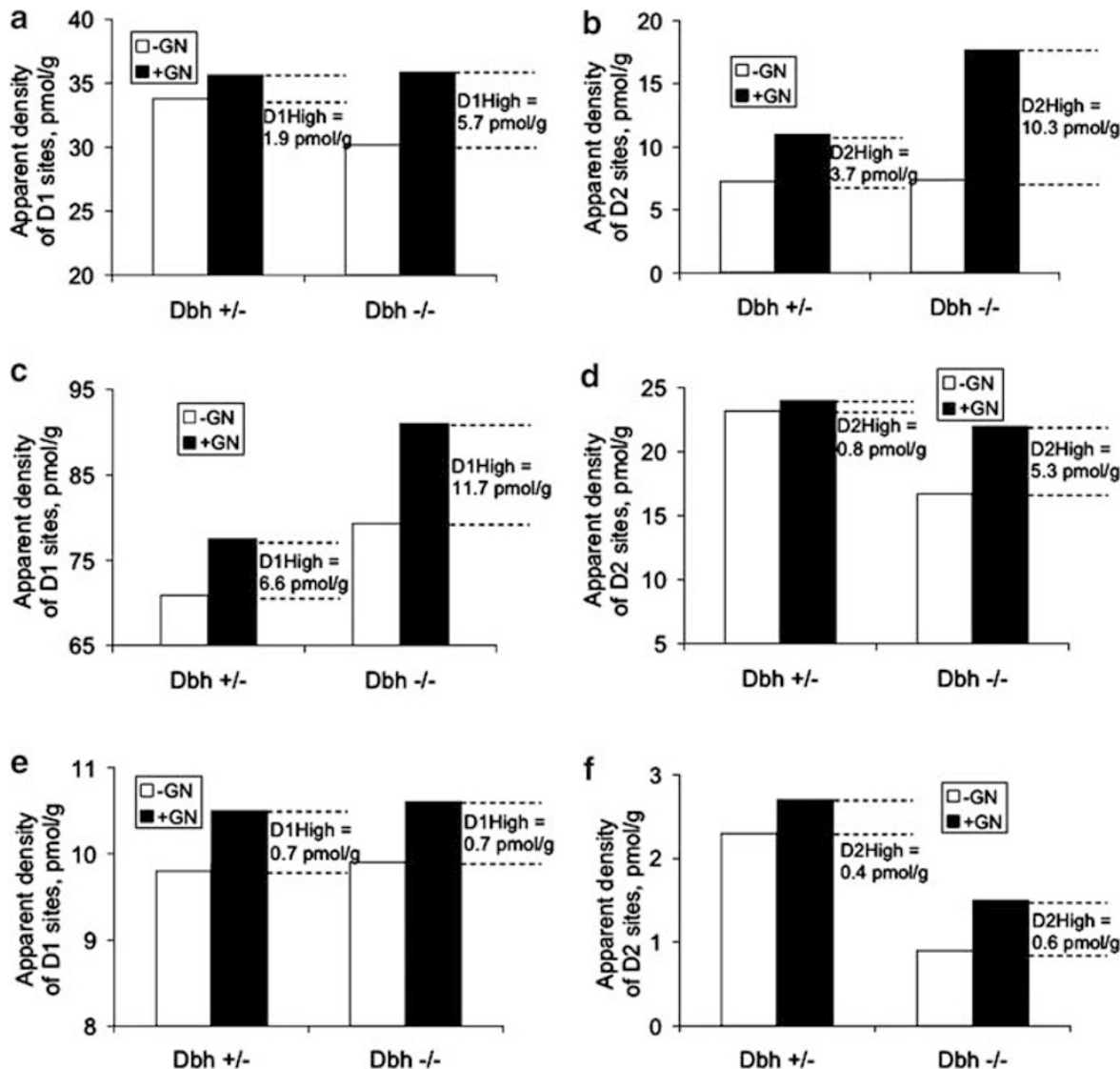

Figure 2 The densities of high-affinity state DA receptors in the NAc and CP are elevated in Dbh-/- mice. Shown are the results from Scatchard analysis of saturation curves of $\left[{ }^{3} \mathrm{H}\right] \mathrm{SCH} 23390$ (D, receptors; $a, c$, and e) and $\left[{ }^{3} \mathrm{H}\right]$ raclopride $\left(\mathrm{D}_{2}\right.$ receptors; $b, \mathrm{~d}$, and $f$ ) binding to homogenized NAc (a and b), $C P$ ( $c$ and $d$ ), and PFC (e and $f$ in the presence (total receptors, black bars) and absence (low-affinity state receptors, white bars) of guanilylimidodiphosphate (GN). The difference between the $-G N$ and $+G N$ conditions represents the density of high-affinity state receptors (DI ${ }^{\text {High }}$, D2 $\left.{ }^{\text {High }}\right)$. The two bars on the left side of each graph represent data from Dbh + / - mice, and the two bars on the right side of each graph represent data from Dbh-/- mice. Tissue from eight animals was pooled for each genotype, and Scatchard analysis was performed in triplicate on each tissue batch. Binding values from the three runs agreed to within $5-8 \%$ of each other. 

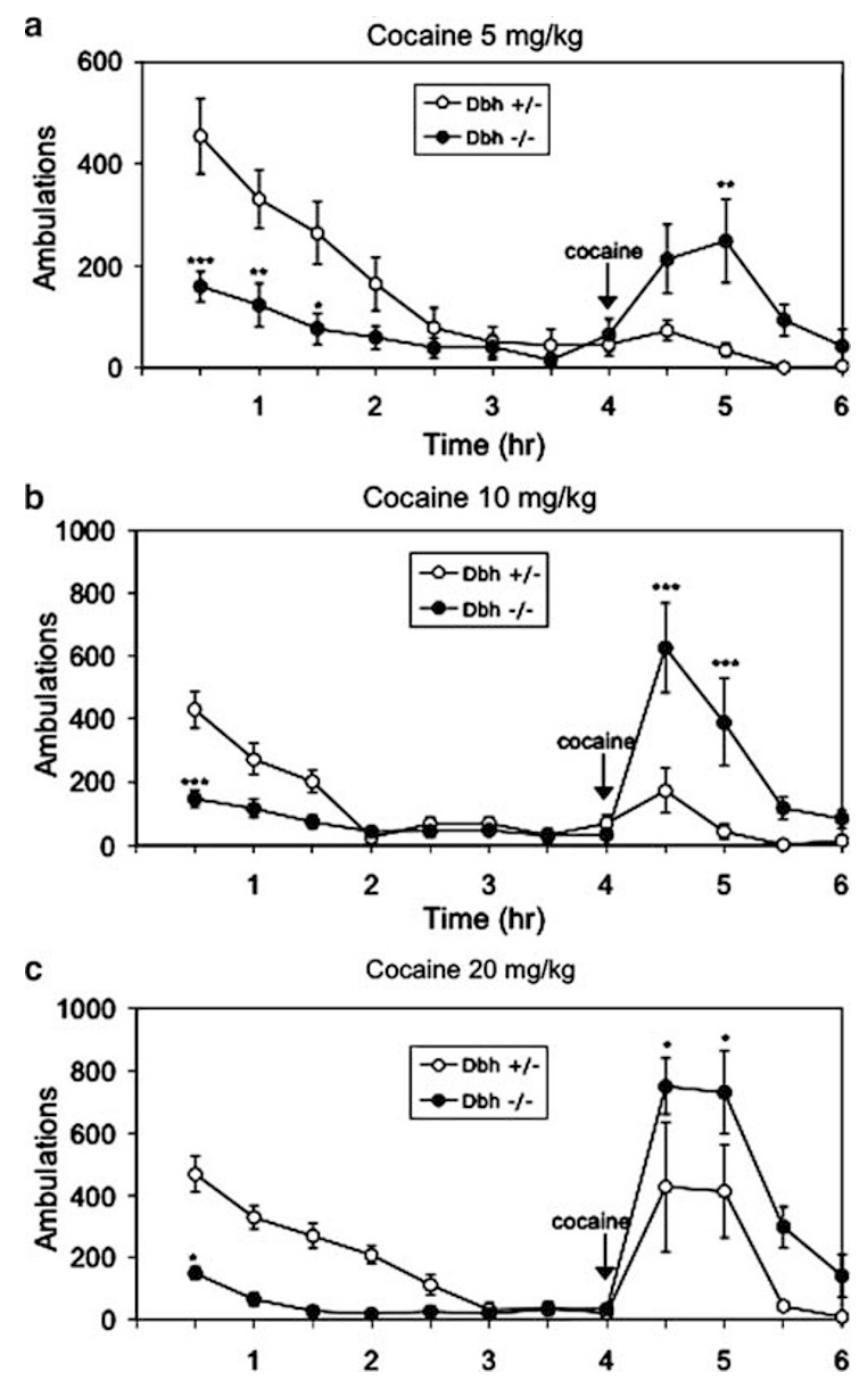

Figure 3 Dbh-/- mice are hypersensitive to cocaine-induced locomotion. Mice were placed in activity chambers and injected with cocaine $4 \mathrm{~h}$ later (black arrows), and ambulations were recorded via infrared beam breaks for two additional hours. Cocaine doses were (a) $5 \mathrm{mg} / \mathrm{kg}$, (b) $10 \mathrm{mg} / \mathrm{kg}$, and (c) $20 \mathrm{mg} / \mathrm{kg}$. $N=7-8$ per group. Values are expressed as mean \pm SEM. $* P<0.05$, $* * P<0.0$ l, $* * * P<0.00$ I compared to $D b h+1-$ mice at that time point.

$D b h+/-$ and $D b h-/-$ mice at multiple time points following cocaine administration (Figure 3). Locomotor activity in response to a novel environment prior to drug administration was reduced in $D b h-1-$ mice, as described previously (Weinshenker et al, 2002; Figure 3).

To determine whether the alterations in DA receptors contributed to the locomotor hypersensitivity of $D b h-/-$ mice to cocaine, saline, the $\mathrm{D}_{1}$ antagonist SCH23390, or the $\mathrm{D}_{2}$ antagonist eticlopride were administered to mice $30 \mathrm{~min}$ prior to cocaine $(20 \mathrm{mg} / \mathrm{kg})$. As serotonergic hyperinnervation of the striatum can occur after DA depletion, we also tested the ability of 5-HT antagonists to prevent the cocaine hypersensitivity of $D b h-/-$ mice. A significant effect of treatment was found for both genotypes (one-way ANOVA: $D b h+/-\mathrm{F}_{5,49}=4.35, \quad P<0.0001 ; \quad D b h-/-\mathrm{F}_{5,48}=12.03$, $P<0.0001)$. Post hoc analysis revealed that both SCH23390 and eticlopride attenuated cocaine-induced locomotion in $D b h+/-$ and $D b h-/-$ mice (Figure 4). In contrast, the

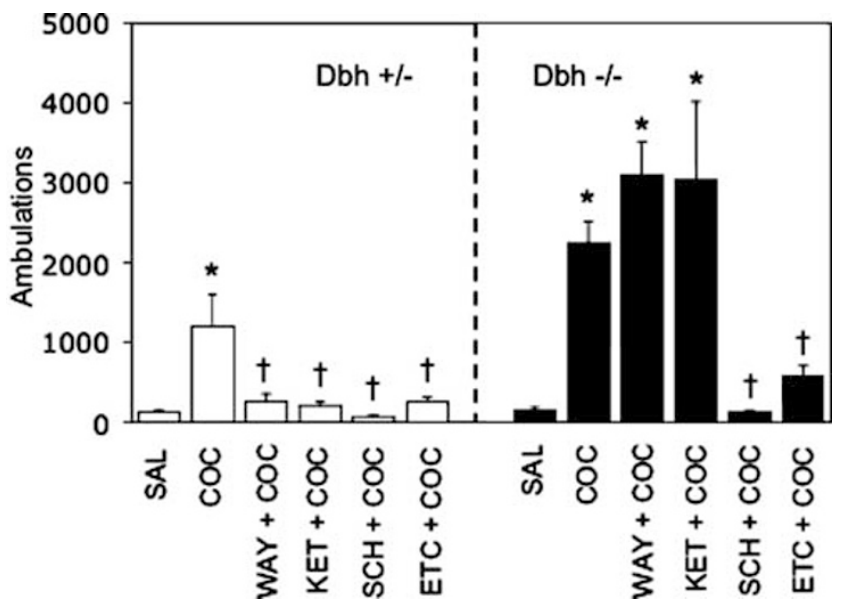

Figure 4 Effects of DA and 5-HT antagonists on cocaine-induced locomotion in Dbh mice. Shown are the total ambulations of Dbh $+1-$ mice (white bars, left of dashed line) and Dbh-/- mice (black bars, right of dashed line) for the $2 \mathrm{~h}$ following administration of saline (SAL), cocaine (COC; $20 \mathrm{mg} / \mathrm{kg})$, the 5-HTIA antagonist WAYI00635 $(0.03 \mathrm{mg} / \mathrm{kg})+$ cocaine (WAY + COC), the $5-\mathrm{HT}_{2}$ antagonist ketanserin $(0.3 \mathrm{mg} / \mathrm{kg})+$ cocaine $(K E T+C O C)$, the $D_{1}$ antagonist $\mathrm{SCH} 23390(0.03 \mathrm{mg} / \mathrm{kg})+$ cocaine $(\mathrm{SCH}+\mathrm{COC})$, or the $\mathrm{D}_{2}$ antagonist eticlopride $(0.3 \mathrm{mg} / \mathrm{kg})+$ cocaine $(E T C+C O C)$. Antagonists were administered $30 \mathrm{~min}$ prior to cocaine. $N=6-12$ per group. Data were analyzed by one-way ANOVA followed by Bonferroni post-hoc tests. * $P<0.05$ compared to saline control for that genotype. ${ }^{\dagger} P<0.05$ compared to cocaine alone for that genotype.

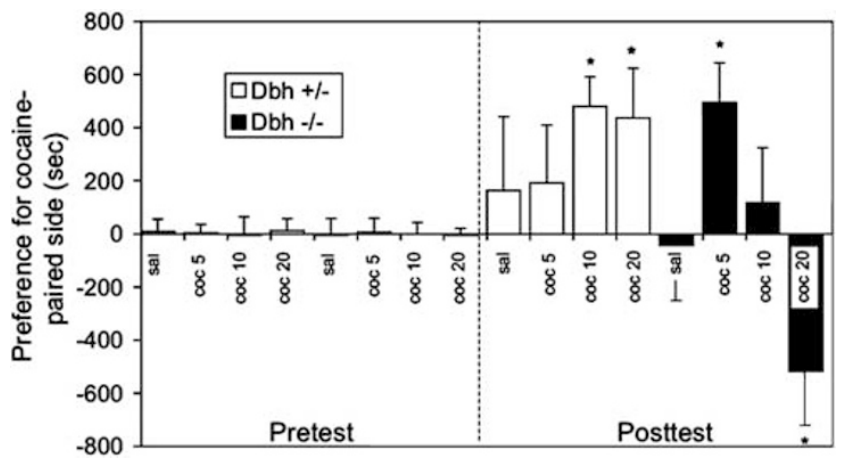

Figure 5 Dbh-/- mice are hypersensitive to cocaine reward and aversion. Shown is the preference of $D b h+/-$ mice (white bars) and Dbh-1- mice (black bars) in seconds for the 'cocaine-paired' (saline, cocaine 5 , 10 , or $20 \mathrm{mg} / \mathrm{kg}$ ) side before (Pretest, left of dashed line) and after (Post-test, right of dashed line) 3 days of pairing. $N=7-10$ per group. Values are expressed as mean \pm SEM. $* P<0.05$ compared to the pretest for that group.

5- $\mathrm{HT}_{1 \mathrm{~A}}$ antagonist WAY100635 and the 5- $\mathrm{HT}_{2}$ antagonist ketanserin attenuated cocaine-induced locomotion in $D b h+/-$ mice, but were completely without effect in Dbh-/- mice (Figure 4).

\section{Altered Cocaine Reward and Aversion in $D b h-/-$ Mice}

To determine whether the alterations of dopaminergic signaling in $D b h-/-$ mice affect psychostimulant reward, we assessed cocaine conditioned place preference in $D b h+/-$ and $D b h-/-$ mice. The side preference of both genotypes before pairing with cocaine and after pairing with saline was essentially random (Figure 5). While $D b h+/-$ mice 
expressed a significant place preference to cocaine at the moderate and high dose (10 and $20 \mathrm{mg} / \mathrm{kg}$ ) but not the low dose $(5 \mathrm{mg} / \mathrm{kg}), \quad D b h-/-$ mice expressed a significant preference only at the low dose and avoided the cocainepaired chamber at the high dose (Figure 5). To determine whether the normal dose response to cocaine was shifted in Dbh-/- mice, we examined whether higher doses of cocaine produced a place aversion in $D b h+/-$ mice. Conditioned place aversion was not observed in $D b h+/-$ using cocaine doses up to $60 \mathrm{mg} / \mathrm{kg}$, the highest dose tested (Figure 5). $D b h+/-$ mice in fact showed a trend towards a place preference at 40 and $60 \mathrm{mg} / \mathrm{kg}$ cocaine, but it was not quite significant in either case (post-test preference for cocaine-paired side at $40 \mathrm{mg} / \mathrm{kg}: \quad+327 \pm 178 \mathrm{~s}, \quad P=0.1$ compared to pretest, $N=10 ; 60 \mathrm{mg} / \mathrm{kg}: \quad+248 \pm 245 \mathrm{~s}$, $P=0.21$ compared to pretest, $N=9$ ).

\section{DISCUSSION}

\section{Regulation of DA Release by NE}

We found that basal extracellular DA levels were attenuated in the NAc and CP of Dbh-/- mice. Consistent with these results, LC lesions decrease striatal DA availability (Russell et al, 1989; Lategan et al, 1990, 1992; Haidkind et al, 2002), resulting in DA receptor supersensitivity (Donaldson et al, 1976; Lategan et al, 1989; Harro et al, 2000). Basal DA release in the PFC was not significantly affected, suggesting that NE is more critical for the basal tone of mesolimbic and nigrostriatal DA neurons than for mesocortical DA neurons. However, it is important to note that the NE transporter (NET) can take up DA, and noradrenergic neurons may release DA as well as NE (Carboni and Silvagni, 2004; Devoto et al, 2005). Therefore, it is possible that basal DA levels in the PFC of $D b h-/-$ mice are maintained by the local release of DA from 'noradrenergic' neurons. This 'ectopic' DA could be synthesized de novo by the 'noradrenergic' neurons or be released from dopaminergic terminals and taken up into the noradrenergic neurons via the NET.

Amphetamine can increase DA release in an impulseindependent manner by acting directly on DA transporters. However, accumbal DA release following systemic amphetamine appears to be primarily impulse-dependent in some mouse strains, and $\mathrm{NE}$ is critical for this aspect of DA outflow (Ventura et al, 2004). Amphetamine-induced burst firing of DA neurons is dependent on $\alpha_{1} \mathrm{AR}$ signaling, and amphetamine-induced DA release in the NAc is attenuated in $\alpha_{1 \mathrm{~B}} \mathrm{AR}$ knockout mice, mice with depletion of $\mathrm{NE}$ in the PFC, and by $\alpha_{1} \mathrm{AR}$ antagonists (Darracq et al, 1998; Shi et al, 2000; Paladini et al, 2001; Auclair et al, 2002; Ventura et al, 2003). Our data confirm and extend these findings. Amphetamine-induced DA release was completely abolished in the NAc of $D b h-/-$ mice, while DA release persisted in the $\mathrm{CP}$ and $\mathrm{PFC}$, although at reduced levels. These results indicate that $\mathrm{NE}$ is required for the maximal increase in extracellular DA observed after psychostimulant administration, and that mesolimbic DA neurons absolutely depend on the noradrenergic system for this response.

The LC, A1, and A2 brainstem cell groups project directly to the VTA and exert excitatory control over DA neuron firing (Jones and Moore, 1977; Simon et al, 1979; Grenhoff et al, 1993, 1995; Grenhoff and Svensson, 1993; Liprando et al, 2004; Mejias-Aponte et al, 2004). In addition, PFC neurons express $\alpha_{1}$ ARs (Palacios et al, 1987; Pieribone et al, 1994 ), and $\alpha_{1} \mathrm{AR}$ antagonists infused directly into the PFC or NE depletion in the PFC attenuate amphetamine-induced DA release in the NAc (Darracq et al, 1998; Ventura et al, 2003). Thus, the lack of both 'direct' and 'indirect' (via the PFC and other structures; Taber et al, 1995; Tong et al, 1996; Marek and Aghajanian, 1999; Carr and Sesack, 2000; Darracq et al, 2001) excitatory noradrenergic inputs to the VTA likely contributes to the reduction of accumbal DA release in $\mathrm{Dbh}-/-$ mice.

\section{DA Receptor Supersensitivity in $\mathbf{D b h}-/-$ Mice}

A reduction in DA availability typically results in the upregulation of DA receptor signaling in terminal regions. For example, DA receptor hypersensitivity is observed after lesions of DA neurons (Arnt, 1985) or genetic DA depletion (Kim et al, 2000). An increase in high-affinity state DA receptors was observed in the NAc and $\mathrm{CP}$, but not the PFC, of $D b h-/-$ mice. As DA availability in the PFC of $D b h-/-$ mice was normal under basal conditions but decreased after amphetamine administration, the increase in striatal highaffinity state receptors correlated with the basal availability of extracellular DA, as opposed to the availability of DA after evoked release. Although the density of both highaffinity state $D_{1}$ and $D_{2}$ receptors was increased in the striatum, Dbh-/- mice were hypersensitive to the behavioral effects of a $D_{2}$ agonist, but not a $D_{1}$ agonist; in fact, Dbh-/- mice are relatively insensitive to $D_{1}$ agonistinduced locomotion (Weinshenker et al, 2002). As $\mathrm{D}_{1}$ signaling in the PFC opposes DA release in the NAc and locomotor activation (Vezina et al, 1991; Ventura et al, 2004), PFC $D_{1}$ receptors may be preferentially activated by $\mathrm{D}_{1}$ agonists in $\mathrm{Dbh}-/-$ mice, although other explanations are possible.

Taken together, these neurochemical changes in DA signaling may explain the behavioral hypersensitivity of $D b h-/-$ mice to amphetamine. We have previously shown that amphetamine-induced locomotion is modestly enhanced in $D b h-/-$ mice, while amphetamine-induced stereotypy is greatly magnified (Weinshenker et al, 2002). DA signaling in the CP is thought to underlie stereotypies. For example, a number of groups have shown that 6-OHDA lesions of the CP abolish amphetamine-induced stereotypy (Kelly et al, 1975; Makanjuola and Ashcroft, 1982). Thus, the persistence of some amphetamine-induced DA release in the CP of $D b h-/-$ mice coupled with the profound striatal DA receptor hypersensitivity likely underlies their stereotypy-related phenotypes. In contrast, the locomotor response to amphetamine has been attributed to DA signaling in the NAc (eg Kelly et al, 1975; Pijnenburg et al, 1975; Makanjuola and Ashcroft, 1982), and it might seem surprising that amphetamine-induced locomotion is intact in $\mathrm{Dbh}-\mathrm{/}-$ mice despite a lack of amphetamineinduced DA release in the NAc. As the locomotor response to amphetamine is blocked by DA antagonists in Dbh-/mice (Weinshenker et al, 2002), we speculate that DA release in other brain regions, such as the $\mathrm{CP}$ and/or PFC, is responsible. This is consistent with the work of Ventura et al (2003), who demonstrated that amphetamine-induced 
locomotion can occur in the absence of DA release in the NAc. Alternatively, DA release in the NAc of $D b h-/-$ mice may occur at levels below our limit of detection, yet be sufficient for locomotor behavior due to receptor hypersensitivity.

\section{Chronic Dbh Deficiency Affects Cocaine Locomotion, Reward, and Aversion}

Our results indicate that, similar to amphetamine, $D b h-/-$ mice are hypersensitive to cocaine-induced locomotion. We assessed the effects of DA and 5-HT antagonists to determine whether the hypersensitivity was mediated by DA and/or 5-HT receptors. WAY100635 and ketanserin were used for three reasons. First, $5-\mathrm{HT}_{1 \mathrm{~A}}$ and $5-\mathrm{HT}_{2}$ receptors modulate DA release and cocaine-induced locomotion in rats (De Deurwaerdère and Spampinato, 1999; Carey et al, 2001; Broderick et al, 2004). Second, serotonergic hyperinnervation of the striatum occurs after DA neuron lesions, and these receptors contribute to the hyperlocomotion observed in monoamine-depleted animals (Stachowiak et al, 1984; Mignon and Wolf, 2002; Zhang et al, 2002; Bishop et al, 2003). Third, the residual locomotor response to psychostimulants in $\alpha_{1 \mathrm{~B}}$ knockout mice is mediated by compensatory $5-\mathrm{HT}_{2 \mathrm{~A}}$ signaling (Auclair et al, 2004). We found that cocaine-induced locomotion in $D b h+/-$ mice was attenuated by DA and 5-HT antagonists, but only the DA antagonists effectively eliminated cocaine-induced locomotion in $\mathrm{Dbh}-/-$ mice. We conclude that the expression of cocaine hypersensitivity of $D b h-/-$ mice is mediated by changes in DA receptors, although changes in 5-HT signaling could contribute to the development of the hypersensitivity.

Interestingly, acute pharmacological inhibition of $\mathrm{DBH}$ or $\alpha_{1}$ ARs has the opposite effect of chronic DBH deficiency; a single injection of the DBH inhibitor disulfiram or the $\alpha_{1} \mathrm{AR}$ antagonist prazosin attenuated psychostimulant-induced locomotion (Maj et al, 1968; Darracq et al, 1998; Weinshenker et al, 2002). In contrast, chronic disulfiram administration increases cocaine sensitization (Haile et al, 2003). These observations indicate that the dopaminergic adaptations in response to the chronic absence of NE, and not the acute lack of NE, underlie the psychostimulant hypersensitivity of $D b h-/-$ mice.

Psychostimulants possess both rewarding and aversive properties. The conditioned place preference (CPP) of Dbh-/- mice to a low dose of cocaine that does not support a CPP in $D b h+/-$ mice suggests a hypersensitivity to cocaine reward. Perhaps the most striking phenotype we observed was the aversion of $D b h-/-$ mice to a dose of cocaine $(20 \mathrm{mg} / \mathrm{kg})$ that produced a place preference in control mice. We attempted to produce a place aversion in control mice by increasing the dose of cocaine used during the conditioning sessions. Even at the highest dose tested $(60 \mathrm{mg} / \mathrm{kg}), D b h+/-$ mice still tended to prefer the cocainepaired side. We did not test higher doses because $60 \mathrm{mg} / \mathrm{kg}$ is near the threshold for cocaine-induced seizures in mice, which would confound the results (eg Golden et al, 2001). Thus, it is not technically correct to say that chronic $D b h$ deficiency produces hypersensitivity to the cocaine place aversion, because the phenotype was never observed in control mice. Rather, there appears to be a novel shift in the balance between cocaine reward and aversion in $D b h-/-$ mice, where the aversive properties of cocaine can become overwhelming and preclude the reward (Ettenberg and Geist, 1991). Importantly, no seizure activity was observed in $D b h-/-$ mice following administration of the cocaine dose $(20 \mathrm{mg} / \mathrm{kg})$ that produced the place aversion. To our knowledge, this is one of the only examples of a conditioned place aversion to cocaine in rodents. Both a lack of NE and hyperdopaminergic signaling could contribute to this phenotype. For example, mice specifically lacking NE in the PFC show a similar place aversion to amphetamine (Ventura et al, 2003), and Dbh-/- mice are hypersensitive to the aversive effects of ethanol (Weinshenker et al, 2000). In addition, because DA release occurs in response to aversive as well as rewarding events (Thierry et al, 1976; Abercrombie et al, 1989; Jensen et al, 2003) and Dbh-/mice have hypersensitive DA receptors, excessive DA signaling may also underlie the aversion.

\section{DBH and Cocaine Dependence}

DBH activity varies between individuals, and this variation has a strong genetic component that is primarily controlled by a single, common polymorphism (Zabetian et al, 2001). Our results suggest that dopaminergic function and psychostimulant responses could be altered in individuals with low DBH activity, a hypothesis that is supported by the human literature. For instance, cocaine-induced paranoia is more prevalent in individuals with genetically low DBH activity (Cubells et al, 2000). Furthermore, the DBH inhibitor disulfiram has shown promise as a treatment for cocaine dependence (Carroll et al, 2004). These findings suggest that genetic or pharmacological inhibition of DBH may increase the aversive effects of cocaine.

\section{ACKNOWLEDGEMENTS}

We thank Sumitomo Pharmaceuticals (Osaka, Japan) for their generous donation of DOPS, $\mathrm{H}-\mathrm{C}$ Guan and $\mathrm{E}$ Catalfamo for technical assistance, and VG Olson for experimental advice. This research has been supported by Ministero della Ricerca Scientifica e Tecnologica (COFIN 2003), Università 'La Sapienza' Ateneo (2002), Ministero della Salute (Progetto Finalizzato RF00.96P and RF03.182P).

\section{REFERENCES}

Abercrombie ED, Keefe KA, DiFrischia DS, Zigmond MJ (1989). Differential effect of stress on in vivo dopamine release in striatum, nucleus accumbens, and medial frontal cortex. $J$ Neurochem 52: 1655-1658.

Arnt J (1985). Hyperactivity induced by stimulation of separate dopamine D-1 and D-2 receptors in rats with bilateral 6-OHDA lesions. Life Sci 37: 717-723.

Auclair A, Cotecchia S, Glowinski J, Tassin JP (2002). Damphetamine fails to increase extracellular dopamine levels in mice lacking alpha 1b-adrenergic receptors: relationship between functional and nonfunctional dopamine release. J Neurosci 22: 9150-9154.

Auclair A, Drouin C, Cotecchia S, Glowinski J, Tassin JP (2004). 5-HT2A and alpha1b-adrenergic receptors entirely mediate dopamine release, locomotor response and behavioural sensiti- 
zation to opiates and psychostimulants. Eur J Neurosci 20: 3073-3084.

Bishop C, Kamdar DP, Walker PD (2003). Intrastriatal serotonin 5HT2 receptors mediate dopamine D1-induced hyperlocomotion in 6-hydroxydopamine-lesioned rats. Synapse 50: 164-170.

Broderick PA, Olabisi OA, Rahni DN, Zhou Y (2004). Cocaine acts on accumbens monoamines and locomotor behavior via a 5HT2A/2C receptor mechanism as shown by ketanserin: 24-h follow-up studies. Prog Neuropsychopharmacol Biol Psychiatry 28: 547-557.

Carboni E, Silvagni A (2004). Dopamine reuptake by norepinephrine neurons: exception or rule? Crit Rev Neurobiol 16: 121-128.

Carey RJ, DePalma G, Damianopoulos E (2001). Cocaine and serotonin: a role for the 5-HT(1A) receptor site in the mediation of cocaine stimulant effects. Behav Brain Res 126: 127-133.

Carr DB, Sesack SR (2000). Projections from the rat prefrontal cortex to the ventral tegmental area: target specificity in the synaptic associations with mesoaccumbens and mesocortical neurons. J Neurosci 20: 3864-3873.

Carroll KM, Fenton LR, Ball SA, Nich C, Frankforter TL, Shi J et al (2004). Efficacy of disulfiram and cognitive behavior therapy in cocaine-dependent outpatients: a randomized placebo-controlled trial. Arch Gen Psychiatry 61: 264-272.

Carroll KM, Nich C, Ball SA, McCance E, Rounsavile BJ (1998). Treatment of cocaine and alcohol dependence with psychotherapy and disulfiram. Addiction 93: 713-727.

Cubells JF, Kranzler HR, McCance-Katz E, Anderson GM, Malison RT, Price LH et al (2000). A haplotype at the DBH locus, associated with low plasma dopamine beta-hydroxylase activity, also associates with cocaine-induced paranoia. Mol Psychiatry 5: 56-63.

Darracq L, Blanc G, Glowinski J, Tassin JP (1998). Importance of the noradrenaline-dopamine coupling in the locomotor activating effects of D-amphetamine. J Neurosci 18: 2729-2739.

Darracq L, Drouin C, Blanc G, Glowinski J, Tassin JP (2001). Stimulation of metabotropic but not ionotropic glutamatergic receptors in the nucleus accumbens is required for the Damphetamine-induced release of functional dopamine. Neuroscience 103: 395-403.

De Deurwaerdère P, Spampinato U (1999). Role of serotonin(2A) and serotonin $(2 \mathrm{~B} / 2 \mathrm{C})$ receptor subtypes in the control of accumbal and striatal dopamine release elicited in vivo by dorsal raphe nucleus electrical stimulation. J Neurochem 73: 1033-1042.

Devoto P, Flore G, Saba P, Fa M, Gessa GL (2005). Stimulation of the locus coeruleus elicits noradrenaline and dopamine release in the medial prefrontal and parietal cortex. J Neurochem 92: 368-374.

Donaldson I, Dolphin A, Jenner P, Marsden CD, Pycock C (1976). The roles of noradrenaline and dopamine in contraversive circling behaviour seen after unilateral electrolytic lesions of the locus coeruleus. Eur J Pharmacol 39: 179-191.

Drouin C, Blanc G, Villegier AS, Glowinski J, Tassin JP (2002a). Critical role of alpha1-adrenergic receptors in acute and sensitized locomotor effects of D-amphetamine, cocaine, and GBR 12783: influence of preexposure conditions and pharmacological characteristics. Synapse 43: 51-61.

Drouin C, Darracq L, Trovero F, Blanc G, Glowinski J, Cotecchia S et al (2002b). Alpha1b-adrenergic receptors control locomotor and rewarding effects of psychostimulants and opiates. $J$ Neurosci 22: 2873-2884.

Ettenberg A, Geist TD (1991). Animal model for investigating the anxiogenic effects of self administered cocaine. Psychopharmacology (Berlin) 103: 455-461.

George TP, Chawarski MC, Pakes J, Carroll KM, Kosten TR, Schottenfeld RS (2000). Disulfiram versus placebo for cocaine dependence in buprenorphine-maintained subjects: a preliminary trial. Biol Psychiatry 47: 1080-1086.
Golden GT, Ferraro TN, Smith GG, Snyder RL, Jones NL, Berrettini WH (2001). Acute cocaine-induced seizures: differential sensitivity of six inbred mouse strains. Neuropsychopharmacology 24: 291-299.

Grenhoff J, Nisell M, Ferre S, Aston-Jones G, Svensson TH (1993). Noradrenergic modulation of midbrain dopamine cell firing elicited by stimulation of the locus coeruleus in the rat. J Neural Transm Gen Sect 93: 11-25.

Grenhoff J, North RA, Johnson SW (1995). Alpha 1-adrenergic effects on dopamine neurons recorded intracellularly in the rat midbrain slice. Eur J Neurosci 7: 1707-1713.

Grenhoff J, Svensson TH (1993). Prazosin modulates the firing pattern of dopamine neurons in rat ventral tegmental area. Eur $J$ Pharmacol 233: 79-84.

Haidkind R, Kivastik T, Eller M, Kolts I, Oreland L, Harro J (2002). Denervation of the locus coeruleus projections by treatment with the selective neurotoxin DSP-4 [ $N$-(2-chloroethyl)- $N$-ethyl-2bromobenzylamine] reduces dopamine release potential in the nucleus accumbens shell in conscious rats. Neurosci Lett 332: 79-82.

Haile CN, During MJ, Jatlow PI, Kosten TR, Kosten TA (2003). Disulfiram facilitates the development and expression of locomotor sensitization to cocaine in rats. Biol Psychiatry 54: 915-921.

Harro J, Merikula A, Lepiku M, Modiri AR, Rinken A, Oreland L (2000). Lesioning of locus coeruleus projections by DSP-4 neurotoxin treatment: effect on amphetamine-induced hyperlocomotion and dopamine D2 receptor binding in rats. Pharmacol Toxicol 86: 197-202.

Jensen J, McIntosh AR, Crawley AP, Mikulis DJ, Remington G, Kapur S (2003). Direct activation of the ventral striatum in anticipation of aversive stimuli. Neuron 40: 1251-1257.

Jones BE, Moore RY (1977). Ascending projections of the locus coeruleus in the rat. II. Autoradiographic study. Brain Res 127: 25-53.

Kelly PH, Seviour PW, Iversen SD (1975). Amphetamine and apomorphine responses in the rat following 6-OHDA lesions of the nucleus accumbens septi and corpus striatum. Brain Res 94: 507-522.

Kim DS, Szczypka MS, Palmiter RD (2000). Dopamine-deficient mice are hypersensitive to dopamine receptor agonists. $J$ Neurosci 20: 4405-4413.

Koob GF, Sanna PP, Bloom FE (1998). Neuroscience of addiction. Neuron 21: 467-476.

Lategan AJ, Marien MR, Colpaert FC (1992). Suppression of nigrostriatal and mesolimbic dopamine release in vivo following noradrenaline depletion by DSP-4: a microdialysis study. Life Sci 50: 995-999.

Lategan AJ, Marien MR, Colpaert FC (1990). Effects of locus coeruleus lesions on the release of endogenous dopamine in the rat nucleus accumbens and caudate nucleus as determined by intracerebral microdialysis. Brain Res 523: 134-138.

Lategan AJ, Mavradis M, Marien M, Colpaert FC (1989). The effects of locus coeruleus lesions on behaviours induced by putative D1 and D2 receptor agonists. Neurosci Res Commun 5: 63-72.

Liprando LA, Miner LH, Blakely RD, Lewis DA, Sesack SR (2004). Ultrastructural interactions between terminals expressing the norepinephrine transporter and dopamine neurons in the rat and monkey ventral tegmental area. Synapse 52: 233-244.

Maj J, Przegalinski E, Wielosz M (1968). Disulfiram and the druginduced effects on motility. J Pharm Pharmacol 20: 247-248.

Makanjuola RO, Ashcroft GW (1982). Behavioural effects of electrolytic and 6-hydroxydopamine lesions of the accumbens and caudate-putamen nuclei. Psychopharmacology (Berlin) 76: 33-40.

Marek GJ, Aghajanian GK (1999). 5-HT2A receptor or alpha1adrenoceptor activation induces excitatory postsynaptic currents 
in layer V pyramidal cells of the medial prefrontal cortex. Eur Pharmacol 367: 197-206.

Mejias-Aponte CA, Zhu Y, Aston-Jones G (2004). Noradrenergic innervation of midbrain dopamine neurons: prominent inputs from A1 and A2 cell groups. Soc Neurosci (abstract \#465.4).

Mignon L, Wolf WA (2002). Postsynaptic 5-HT(1A) receptors mediate an increase in locomotor activity in the monoamine-depleted rat. Psychopharmacology (Berlin) 163: 85-94.

Mohammed AK, Danysz W, Ogren SO, Archer T (1986). Central noradrenaline depletion attenuates amphetamine-induced locomotor behavior. Neurosci Lett 64: 139-144.

Palacios JM, Hoyer D, Cortes R (1987). alpha 1-Adrenoceptors in the mammalian brain: similar pharmacology but different distribution in rodents and primates. Brain Res 419: 65-75.

Paladini CA, Fiorillo CD, Morikawa H, Williams JT (2001). Amphetamine selectively blocks inhibitory glutamate transmission in dopamine neurons. Nat Neurosci 4: 275-281.

Paxinos G, Franklin KBJ (1997). The Mouse Brain in Stereotaxic Coordinates. Academic Press: San Diego, CA.

Petrakis IL, Carroll KM, Nich C, Gordon LT, McCance-Katz EF, Frankforter $\mathrm{T}$ et al (2000). Disulfiram treatment for cocaine dependence in methadone-maintained opioid addicts. Addiction 95: 219-228.

Pieribone VA, Nicholas AP, Dagerlind A, Hokfelt T (1994). Distribution of alpha 1 adrenoceptors in rat brain revealed by in situ hybridization experiments utilizing subtype-specific probes. J Neurosci 14: 4252-4268.

Pijnenburg AJ, Honig WM, Van Rossum JM (1975). Inhibition of d-amphetamine-induced locomotor activity by injection of haloperidol into the nucleus accumbens of the rat. Psychopharmacologia 41: 87-95.

Russell VA, Lamm MC, Allin R, de Villiers AS, Searson A, Taljaard JJ (1989). Effect of selective noradrenergic denervation on noradrenaline content and $\left[{ }^{3} \mathrm{H}\right]$ dopamine release in rat nucleus accumbens slices. Neurochem Res 14: 169-172.

Seeman P, Tallerico T, Ko F, Tenn C, Kapur S (2002). Amphetamine-sensitized animals show a marked increase in dopamine D2 high receptors occupied by endogenous dopamine, even in the absence of acute challenges. Synapse 46: 235-239.

Seeman P, Weinshenker D, Quirion R, Srivastava LK, Bhardwaj SK, Grandy DK et al (2005). Dopamine supersensitivity correlates with D2High states, implying many paths to psychosis. Proc Natl Acad Sci USA 102: 3513-3518.

Seeman P, Niznik HB, Guan HC, Booth G, Ulpian C (1989). Link between D1 and D2 dopamine receptors is reduced in schizophrenia and Huntington diseased brain. Proc Natl Acad Sci USA 86: 10156-10160.

Shi WX, Pun CL, Zhang XX, Jones MD, Bunney BS (2000). Dual effects of D-amphetamine on dopamine neurons mediated by dopamine and nondopamine receptors. J Neurosci 20: 3504-3511.

Simon H, Le Moal M, Stinus L, Calas A (1979). Anatomical relationships between the ventral mesencephalic tegmentum - a 10 region and the locus coeruleus as demonstrated by anterograde and retrograde tracing techniques. J Neural Transm 44: $77-86$.
Snoddy AM, Tessel RE (1985). Prazosin: effect on psychomotorstimulant cues and locomotor activity in mice. Eur J Pharmacol 116: $221-228$.

Spanagel R, Weiss F (1999). The dopamine hypothesis of reward: past and current status. Trends Neurosci 22: 521-527.

Stachowiak MK, Bruno JP, Snyder AM, Stricker EM, Zigmond MJ (1984). Apparent sprouting of striatal serotonergic terminals after dopamine-depleting brain lesions in neonatal rats. Brain Res 291: 164-167.

Swanson LW, Hartman BK (1975). The central adrenergic system. An immunofluorescence study of the location of cell bodies and their efferent connections in the rat utilizing dopamine-betahydroxylase as a marker. J Comp Neurol 163: 467-505.

Taber MT, Das S, Fibiger HC (1995). Cortical regulation of subcortical dopamine release: mediation via the ventral tegmental area. J Neurochem 65: 1407-1410.

Thierry AM, Tassin JP, Blanc G, Glowinski J (1976). Selective activation of mesocortical DA system by stress. Nature 263: 242-244.

Thomas SA, Marck BT, Palmiter RD, Matsumoto AM (1998). Restoration of norepinephrine and reversal of phenotypes in mice lacking dopamine $\beta$-hydroxylase. $J$ Neurochem 70: 2468-2476.

Thomas SA, Matsumoto AM, Palmiter RD (1995). Noradrenaline is essential for mouse fetal development. Nature 374: 643-646.

Tong ZY, Overton PG, Clark D (1996). Stimulation of the prefrontal cortex in the rat induces patterns of activity in midbrain dopaminergic neurons which resemble natural burst events. Synapse 22: 195-208.

Ventura R, Alcaro A, Cabib S, Conversi D, Mandolesi L, PuglisiAllegra S (2004). Dopamine in the medial prefrontal cortex controls genotype-dependent effects of amphetamine on mesoaccumbens dopamine release and locomotion. Neuropsychopharmacology 29: 72-80.

Ventura R, Cabib S, Alcaro A, Orsini C, Puglisi-Allegra S (2003). Norepinephrine in the prefrontal cortex is critical for amphetamine-induced reward and mesoaccumbens dopamine release. J Neurosci 23: 1879-1885.

Vezina P, Blanc G, Glowinski J, Tassin JP (1991). Opposed behavioural outputs of increased dopamine transmission in prefrontocortical and subcortical areas: a role for the cortical D1 dopamine receptor. Eur J Neurosci 3: 1001-1007.

Weinshenker D, Miller NS, Blizinsky K, Laughlin ML, Palmiter RD (2002). Mice with chronic norepinephrine deficiency resemble amphetamine-sensitized animals. Proc Natl Acad Sci USA 99: 13873-13977.

Weinshenker D, Rust NC, Miller NS, Palmiter RD (2000). Ethanolassociated behaviors of mice lacking norepinephrine. J Neurosci 20: 3157-3164.

Zabetian CP, Anderson GM, Buxbaum SG, Elston RC, Ichinose H, Nagatsu $\mathrm{T}$ et al (2001). A quantitative-trait analysis of human plasma-dopamine beta-hydroxylase activity: evidence for a major functional polymorphism at the DBH locus. Am J Hum Genet 68: 515-522.

Zhang K, Davids E, Tarazi FI, Baldessarini RJ (2002). Serotonin transporter binding increases in caudate-putamen and nucleus accumbens after neonatal 6-hydroxydopamine lesions in rats: implications for motor hyperactivity. Brain Res Dev Brain Res 137: $135-138$. 